\title{
CORPORATE GOVERNANCE AND CREATIVE ACCOUNTING: TWO CONCEPTS STRONGLY CONNECTED? SOME INTERSTING INSIGHTS HIGHLIGHTED BY CONSTRUCTING THE INTERNAL HISTORY OF A LITERATURE
}

\author{
Alina Beattrice Vladu ${ }^{l(*)}$ \\ Dumitru Matiş ${ }^{2(* *)}$
}

\begin{abstract}
Corporate governance is concerned with the relationships between a business's management and its board of directors, shareholders and lenders and its other stakeholders such as employees, customers, suppliers, and the community in which activates. The connection between this topic and creative accounting was debated in the literature since the latter occurrence is related to the weakness of the first. Our study offers interesting insights into this strong connection by examining the relevant ideas developed previously in the literature with the scope of understanding, reinterpreting and rediscovering from interesting points of view this association in our search for responsibility in the economic environment. By conducting this study we wanted to reinforce the role of literature analyst as an interpreter who contributes meaning to the present state of the art.
\end{abstract}

Key words: corporate governance, creative accounting, Papineau`s hierarchy

JEL codes: $M 41$

\section{Introduction}

Both concepts are treated in the literature extensively and the difference employed regards the perception of each. While the first concept is treated and accepted as having a general meaning, the latter is considered to be controversial in terms of meanings and acceptance.

In this regard its conceptual delimitation is considered to be necessary in the introduction of this study since the meanings attributed reflect also our views.

The concept "creative accounting" assimilates various definitions in the literature and it is examined under two important viewpoints: a positive one and a negative one.

From a positive viewpoint, it may seem that creative accounting connotes invention of accounting principles and techniques to recognize changes in economic, social, political and also business environments and recognizes genuine changes in accounting practice. From a negative viewpoint, creative accounting means undesirable practices which assimilates unethical elements for attracting providers of the capital by presenting an misleading and deceptive state of a certain firm`s affairs. Most of the conceptual delimitation regarding creative accounting is related to those two viewpoints and the general trend identified in the literature supports the negative viewpoint.

The practice of creative accounting has the power to distort the underlying financial performance of a firm, making more difficult for an investor or financial analyst to assess the performance of the firm and to compare between different companies. For this reason creative accounting as a deceiving practice conflicts with the basic aim of accounting regulation transforming the exercise of standard setting in a redundant feature on one hand and on the other

\footnotetext{
1 PhD Student, Babes-Bolyai University Cluj-Napoca, Faculty of Economics and Business Administration, beattrice.vladu@econ.ubbcluj.ro

${ }^{2}$ Full Professor, PhD, Babes-Bolyai University Cluj-Napoca, Faculty of Economics and Business Administration, dumitru.matis@econ.ubbcluj.ro
} 
hand providing an unfair advantage to companies that are able to successfully practice this deceiving exercise.

The opinions regarding creative accounting practice, as an instrument of deceiving are various and the definitions multiple. The scope of our study was not to reproduce this definitions (even if this demarche can be useful for a better understand of the latter topic) but more to construct an internal history of the relevant literature that approached this topic. In regarding we consider more relevant to approach the creation of a network of core terms for the literature in question and to identify the primary and secondary core terms used to describe this topic into the international relevant research community. In this respect we used Papineau`s (1976) concept of descending order of core terms to demarche those terms that are central to all researchers with the scope of a thorough understanding of the development of a particular literature.

Since the scope of the article is not to develop the epistemology of this construct and moreover the association with the corporate governance construct, we debated only four different opinions regarding the creative accounting meaning under the aegis of Papineau`s (1976) hierarchy of core terms as following:

- As regarding Metcalf (1977:188) approaching we identified as primary core term in explaining creative accounting the "accounting techniques" that permit corporations to report financial results that may not accurately portray of business activities. As secondary core terms we can further develop based on its assumptions the subjective and objective manner in which the accounting techniques are used;

- From Naser (1993:2) we can identify as primary core terms for explaining creative accounting the "accounting figures". In this respect the preparers motivations are important since their desire is to take advantage of the existing rules in order to succeed to accomplish their particular goals;

- Citron (1995) view provide other primary core term as "accounting rules" and further as secondary core terms the implicit desire of preparers to " stretch" the rules and "mislead" the reader of financial statements;

- Amat and Gowthorpe (2004) opinion regarding creative accounting provide an interesting sight since it provides two types of primary core terms as "ambiguities" and " discontinuities" of the law. The secondary core terms comprise the implications of the first one together with the desire of mislead rather than to help the intended used.

In our opinion creative accounting can be defined as a mean being used by the companies in order to adapt, develop and become more competitive in the turbulent environments in which they operate, adaptation that requires highly adaptive professionals able to generate creative ideas even if these employ interpreting grey areas to their advantage being less prudent almost all the time; seek for loopholes in specific rules being not as consistent as should be or develop devices which regulators have not thought to forbid.

\section{Theoretical framework for sustaining our research question}

In terms of linking the two concepts we consider the definition elaborated by Shleifer and Vishny (1997) as representative since we can identify the roots of creative accounting behavior as the following confirms the potential existence of inappropriate conduct of management: "Corporate governance encompasses all the provisions and mechanisms that guarantee the assets of the firm are managed efficiently and in the interests of the providers of finance, mitigating the inappropriate expropriation of resources by managers or any other party to the firm".

Managers sometimes mislead shareholders regarding the underlying economic performance of a certain company or may influence contractual outcomes that depend upon reported accounting figures (Healy, 1985; Perry and Williams, 1994; DeFond and Jiambalvo, 1994). By using judgments in financial reporting and through structuring transactions they may alter financial reports and as a consequence, this path may lead to a set of financial statements that do not provide 
a true and fair view of the economic activities of a company. Managerial discretion in the application of accounting methods used to report firm performance is not considered to be manipulative until this particular discretion is used with the intent to manipulate reported results. This is related also to the fact that managers may focus on short-term personal incentives such as maximizing salaries, bonuses, and other short-term compensations, rather than focus on the longterm economic success of the firm. All those doubts appear where a separation of the ownership from the control of a corporation exists and in this respect the conflict that arises is described by the Agency theory.

In the context of Agency Theory the firm is considered to be a legal fiction that serves as a focus for complex process that is characterized by conflictual features of the objectives of individuals (Jensen and Meckling, 1976). The conflicts are related to sharing the economic resources and the lack of confidence, these conflicts between the shareholders and managers being considered in the literature to be the root of creative accounting. Most studied conducted in the literature are concentrated so far on the relationship between shareholders-management interaction that involves the intensively debated conflict of interests as the frameworks developed by Demski (1994), and further Christensen and Feltham (2005) explained.

The topics corporate governance and creative accounting practices are discussed in the literature in the context of internal demand for manipulative behavior which emanates from the contracting value of earnings management in the principal-agent relationships between shareholders and managers (Dye, 1988).

This particular conflicts of interests inherent in agency relationships, sometimes are limited having the fact that shareholders overlooked and accept deliberate manipulations of accounts becoming in this way "unwitting accessories to manipulation" (Gowthorpe and Amat, 2005) as they are accepting the fact that part of manipulation of accounts advantage them.

The importance of corporate governance studies in the area of creative accounting presented under all its forms of manifestation is related to the general trend presented in the literature that poor governance induce or sustain a manipulative behavior. Also discussions are regarded the fact that poor governance results in inflated compensation packages that induce CEOs to act in a manipulative manner. On the other hand, recent studies conducted in the literature approached the problem of poor corporate governance primarily with the scope of discovering the features that contribute to this state and documented that the causality of this demarche is represented by the earnings management and further extended to accounts manipulation.

In this respect, further empirical studies are needed to detect surely the association between accounts manipulation and corporate governance and assess the importance of each other and the way that they reinforce each other.

The topic of information asymmetry is also discussed since no approaching regarding corporate governance in the area of creative accounting omits it and since the theory regarding information asymmetry has the potential to explain the multiple incentives found on the financial market to manipulate accounting data and further to assess the consequence of such behavior. The work of Vickrey (1945); Akerlof (1970, 1976); Mirrlees (1971); Spence (1973); Rothschild and Stiglitz (1976) is examined since they developed the pioneering studies regarding asymmetry of information. By understanding their work we can have a thoroughly understanding of the markets behavior with consequences upon our area of research since information asymmetry is regarded as a also as a genesis point for manipulative behavior. The general view when it comes to explain information asymmetry is that one side of the market has better information that the other. In the context of corporate governance the CFO and the board of the company knows more than the shareholders and other users of accounting information about the profitability of the company.

Five theories have provided the theoretical underpinning for research opportunistic behavior in the area of corporate governance. Agency theory; legitimacy theory; institutional theory; signaling theory and stakeholder theory describe different point of views in association with 
managerial opportunistic behavior. By examining those theories the association of corporate governance with creative accounting behavior is interpreted and thoroughly explained. In regarding of these theories our goal was to explain several components that are related to our area of research not to thoroughly explain the theories or to assess their evolution or impact as independent theories.

Based on the relevant theoretical framework, we developed the research questions as following:

- Are there significant theories that can explain the importance of treating those concepts under the aegis of association?

- The empirical studies that approached those concepts under the aegis of connectivity have the potential to explain this association based on empirical data?

\section{Methodology}

In this regard we were interested in choosing an appropriate methodology that could enable us to answer the questions identified and further to achieve our aim. Since this study is not an empirical study, but a fundamental research we adopted previously tried methods used in the literature for this kind of studies and we approached the idea of constructing an internal history of literature in order to be able to answer to our research question. In this respect we efficiently identified the principal authors and papers by "backtracking" them from the recent and also relevant contribution to the literature.

We identified the theme and the issues approached on the basis of a general sampling of the literature. As implicit methodology adopted it was the inductive methodology that sustain the main idea of the fact that general conclusions regarding the development of a subject are drawn from a sample of literature. Since this study is not an empirical one, the problems associated with the applying of such a method are not found in our study.

\section{Findings - Discussions based on relevant theories and discussions that emphasize the approached association}

There are two different patterns through which companies are financed, both of them affecting accounting earnings. Each one of the two patterns of financing the companies is related to the corporate governance model that prevails in a particular country. If a certain country belongs to the Anglo-American accounting model the determinant corporate governance model is the shareholder model. In this context the capital market has a great role in financing companies and as a consequence of that great importance will be put in information presented to shareholders. Companies in this context are dominated by equity and there is a great separation between managers and owners and as a consequence of this the information asymmetry that exists in the complex may have the power to give rise to corporate privileged structures as management. In this particular context the incentives to manipulate accounting information are considered to be stronger.

In a country belonging to Euro-Continental accounting model, the corporate governance model that is reflected in this context is the stakeholder model. In this context, great emphasis is placed on the information presented to the creditors (e.g. banks) since the finance pattern of the companies is related to them. Accounting rules are conservative as they serve mainly for the creditor's needs of information.

In both corporate governance models, information asymmetry is seen as a genesis point for creative accounting occurrence or earnings management behavior. In a context of information asymmetries, the managers can opportunistically manage the accounting number in order to present the results that are expected by the market. The main purpose appears as a consequence of the desire to avoid the negative consequences that of the news that raised the alarm would represent in terms of stock price performance. 
Information asymmetry is a topic that first developed as a prolific part of economic theory when for most than two decades researchers examined incentives and market equilibrium in situations with asymmetric information. The economic theory comprised The Theory of markets with asymmetric information, developed by pioneering studies like those conducted by: George Akerlof (University of California, Berkeley, 1970, 1976), Michael Spence (Stanford University, 1973) and Joseph Stiglitz (Columbia University, 1976). The importance of those studies relies in the fact that various tools for analyzing a broad spectrum of issues were developed since their applications extend from traditional agricultural markets to financial markets. Once extended to financial markets the genesis point for introducing the term and its associating features is accounting become a fact.

Akerlof (1970) article The Market for Lemons: Quality Uncertainty and the Market Mechanism is considered to be the most important contribution to the literature on economics of information. This paper introduces the universal idea that information asymmetry governs the markets and in the same time opens points to broad applications. In his 1976 article entitled The Economics of Caste and the Rat Race and Other Woeful Tales discuss about the significance of informational asymmetries in widely different contexts and provide information regarding undesirable equilibrium on the markets with information asymmetry. Both studies are important for area of research having the fact that the theory of information asymmetry is approached and the concept thoroughly explained. Another fundamental insight and extremely important for our area of research is that economic agents, according to the author, attempts to protect themselves from the adverse consequences of informational asymmetries may explain existing institutions that guarantee the good functioning of markets. This original approach has generated in the following years an entire literature analyzing how economic institutions may mitigate the consequences of asymmetric information.

Spence's most important work (1973) demonstrates how agents in a market can use signaling to counteract the effects of adverse selection. In this context, signaling comprise observable actions taken by economic agents in order to convince the opposite party of the value or quality of their products. Even if author`s article Job Market Signaling (1973) deal with labor market, the theory of signaling can be extended to different markets. The essence of Signaling Theory can be applied in our area of research too, this being the reason why the work of Spence (1973) was discussed in our study.

Stiglitz`s article with Rothschild entitled Equilibrium in Competitive Insurance Markets: An Essay on the Economics of Imperfect Information (Rothschild and Stiglitz, 1976) represent a complement analyses for Akerlof $(1970,1976)$ and Spence $(1973,1974)$. The research question that guided their work is the following: "what can uniformed agents do to improve their outcome in a market governed by information asymmetry?". Without any doubt complete and opportune information represent the success of any affair. Since the authors developed by their work the paradigm of classification of equilibrium, their work is considered extremely important in microeconomics theory and in information economics in particular, where their work is the most cited one. Their work was examined in the context of our research based upon the fact that they were the first one that asserted that economic models may be quite misleading if we disregard informational asymmetries. Every model developed that has the potential to explain a certain behavior can fail to achieve its goal if the market in which it operates is characterized by information asymmetry.

The work of Vickrey (1945) and Mirrlees (1971) is also important for our area of research since they bring fundamental contributions to the theory of incentives under asymmetric information.

In the context of accounting, corporations have stakeholders who rely on the validity of financial information provided to them. This category is defined as various groups and individuals 
who benefit from them or are harmed by, and whose rights are violated or respected by corporate actions (Donaldson and Werhane, 1999: 251).

The previous definition introduces the concepts of Agency Theory, the theory that dominates this field of research. Since the root of opportunistic behavior is considered to be located in the problems that this theory rise having the fact that this particular theory is seen as the theory of conflicts between managers and shareholders where the first category are prompted to manipulate the latter category perceptions and further influencing their decisions on financial performance and future economic trend of the company. It is this particularly theory that implemented in the area of manipulation of accounts the idea that managers are not neutral in presenting accounting financial statements (Sydserff anf Weetman, 1999).

In this respect two different points of view are discussed. The first one is related to the fact that managers are trying to provide information to users of accounting information in order to overcome the information asymmetry that take place between their knowledge and outsiders. The scope of this demarche is considered to be in this context enhancing the share performance and increasing managerial compensation (Baginski et al., 2000). The other view that is related to Agency Theory and gained more advocates is related to the fact that managers provide information through the channel of disclosure in order to achieve their own goals. In this context the disclosure strategies are regarded as opportunistic (Abrahamson and Park, 1994; Aerts, 2005). A more general view was asserted by Cormier, Aerts, Ledoux, Magnan (2009) that extended the literature on voluntary disclosure by examining the impact of precision attribute of social and human capital disclosure on information asymmetry. The results documented that quantitative disclosures reduces share price volatility and firms appear to take into account ultimate costs and benefits to shareholders when determining their disclosure. The general idea of the study was the fact that efficient governance leads to more disclosure.

Legitimacy Theory has also been used in explaining corporate reporting disclosure practices but not like the previous one. According to this theory the main scope of disclosure is to alter perceptions regarding the legitimacy of the organization since disclosure are not regarded as voluntary channels of information but as responses to public pressure (Hooghiemstra, 2000) since firms are considered to have a social contract with the society they activate since their survival depends of societal norms. In this respect sometimes firms may focus more on the need for information on customers' needs rather than investor's needs when preparing the annual reports (Ogden and Clarke, 2005).

While the Legitimacy Theory asserts that firms respond to social norms, the Institutional Theory asserted that firms respond to institutional expectations but adopting norms and procedures in order to reduce inspection by internal and external constituents. In this respect managers are assumed to respond to institutional pressures when disclose their financial statements. A practical example can be found in the study conducted by Bansal and Clelland (2004). The authors found that managers respond to environmental pressure disclosing environmental liabilities by which the commitment to the environment can be assessed. The Stakeholder Theory is similar to Legitimacy Theory, the differences const in the fact that firms prepare the financial statements as a response and demand of various groups of stakeholders (e.g. employees, customers, government agencies, etc). This Theory is important for area of research since it regard firms under an aegis of manipulation with the scope of altering the perceptions of a particular group of stakeholder.

Signaling Theory is focused on the behavior of managers in well performing firms who tend to disclose the performance with greater transparency in their presentation of financial statements. In this respect the study conducted by Smith and Taffler (1992) is representative. The precepts of this theory are important for our area of research since it assess the managerial behavior with implication regarding firm performance.

The scope of discussing those theories in our area of research it given by the fact that each one of them introduces different managerial incentives translated further in different managerial 
actions. While Agency Theory and Signaling Theory are preoccupied by the investor's informational data regarding financial performance and the channels related to this, the other three theories consider that society as a whole that comprise also the stakeholders particular needs of information, is comprised in the audience of firms' disclosures that in those cases offers a different view since in those disclosures social and environmental performances are approached proving the fact that manipulation is not related only to financial performance.

Findings - Discussions based on relevant empirical work that documented the association of corporate governance and creative accounting

The pioneering studies in accounting area that investigated the relationship between information asymmetry and earning management were conducted by Dye (1988) and Trueman and Titman (1988), who asserted that the existence of information asymmetry is the necessary condition for earnings management. With this study, information asymmetry is brought directly in accounting area since it was associated with manipulative behavior. Since then and to the present times, information asymmetry is regarded in the accounting literature just the same.

Schipper (1989) also approached the relationship between the information asymmetry and earnings management and concluded that when information asymmetry is high the shareholders and stakeholders do not have sufficient information, resources, incentives or access in order to monitor manager's actions fact that gives rise to earnings management practices. The same opinion is shared by Warfield, Wild and Wild (1995) who tested this hypothesis in a broad sample setting as well as around seasoned equity offerings. The results in a broad sample setting suggested a significant, positive relationship between earnings management and information asymmetry. Those results are consistent with the fact that the greater information asymmetry is between the managers and its shareholders the more likely the company is engaged in earnings manipulations.

Others results of the studies conducted around seasoned equity offerings serves as a second setting to test the relationship between information asymmetry and earnings management. The empirical study conducted Rangan (1998), indicate the fact that management faces the incentives to manage the earnings upward prior to seasoned equity offerings in order to maximize the offer prices of the shares. This is a proof that they are willing to focus on short-term objectives rather on longterm objectives.

Richardson (2000) tested the hypothesis that the magnitude of information asymmetry affects the magnitude of earnings management practiced by firm's managers. The author conducted a direct test of Dye (1988) and Trueman and Titman (1988) theory that the presence of information asymmetry is a necessary condition for earnings management and extended the argument by introducing the relationship between them assessed in terms of magnitude. The tests of the hypothesis provided evidence of the predicted positive relationship between information asymmetry and earnings management. Positive association was also documented between the quality of corporate governance and earnings management in the study conducted by Ali Shah, Ali Butt, Hasan (2009).

When those two topics are treated simultaneously (e.g. corporate governance and creative accounting), the third topic of information asymmetry between firms and other stakeholders arise. In this context the studies comprised in the literature also examined the way in which "gatekeepers are monitors that are supposed to alleviate the information asymmetry", like: analysts, institutional shareholders who are blockholders and activists, boards of directors and their audit committees, auditors, the press, and investment bankers, and credit agencies (Ronen and Yaari, 2008, pp. 54).

The role of corporate governance complex mechanism is to minimize information asymmetry and to ensure compliance with mandated reporting requirements while maintaining the credibility of a firm`s financial statements and safeguard against manipulative behavior (Dechow et al. 1996; Davidson et al., 2005). Corporate managers in their fiduciary role as the stewards of stockholders' assets are expected to run the company primarily in the best interest of the providers 
of the capital and as a consequence should focus to maximize long-term earnings correlated with improved business strategies, objective successful operations and sustainable development.

When corporate governance area intersects with creative accounting presented under all its forms of manifestation, information asymmetry is not the only problem involved. The fact that managers tend to focus on short-term personal incentives (e.g. enhance market value of the stock for stockholders or to increase income-based compensation for management like bonuses or maximizing salaries) rather than focus on long-term economic success of the firm could harm seriously the future of the firm. This particular vision is usually accompanied with aggressive use of manipulating techniques which causes the topic of creative accounting to rise to a level of importance in the area of corporate governance and not only.

Dechow et al., (1996) issued a part of the previous opinion based on their empirical study that documented a strong association between earnings management occurrence and the lack of features of a strong corporate governance, features as: the absence of an audit committee; the combination of the CEO and founder roles; the combination of the CEO and the chair of the board roles; board of directors dominated by insiders; and absence of an external blockholder (i.e. watchdog) monitoring management.

Further studies sustain their opinion. The empirical study conducted by Davidson et al. (2005) concluded that boards and audit committees dominated with non-executive members are significantly associated with lower possibility of earnings management. Another empirical study demonstrated that voluntarily established audit committee has an important role in limitation of the manipulative behaviors (Jaggi and Leung, 2007).

Until now we have seen how corporate can influence accounting items but this approach is not complete. The other part of the approach is that cosmetic accounting and accounting irregularities also had the power to influence corporate governance underlying principles.

Following accounting scandals at the prominent companies discussed above, there have been important changes in corporate governance since most of the scandals were discussed and their magnitude assessed in the context of a weak corporate governance mechanism. Since corporate governance previous features were accused of comprising features that further induced and maintain a climate of opportunistic behavior, many changes were proposed and there has been a sweeping overhaul of regulations on corporate governance. From all the changes employed in the context of corporate governance we consider the following as having the most immediate effect in limit manipulative behavior. Since the most prominent accounting scandals were in USA, the change of corporate governance mechanisms came also from this accounting environment. As we approach above, two events changed the corporate governance mechanism and from this point the corporate mechanisms all over the world changed. First regulation event took place in July 2002, when the USA adopted the Sarbanes-Oxley Act which applies to all public companies with stock traded in the United States. Among its many provisions, the Sarbanes-Oxley Act required a substantial change of vision when required that a company`s board to have a majority of independent directors and that the board's audit committee consist entirely of independent directors, further to have at least one member with financial expertise and to restrict the types of non-audit services that the outside auditor can provide (all these changes were adopted based on accounting scandals experience).

The second event took place in the end of 2003 when the biggest capital markets in the world (e.g. NYSE, NASDAQ, and AMEX) adopted new sets of corporate governance rules that apply to most of their listed companies. Their rules were based on Sarbanes-Oxley Act and were designed to avoid serious accounting problems in the future.

In 2005 an empirical study was conducted by Agrawal and Chadha with the main goal of examining id corporate governance mechanisms are related to the possibility of a company restating its earnings. After examining a sample of 159 U.S. public companies that restated earnings the authors compared the results with an industry-size matched samples of control firms and concluded 
that several key governance characteristics are essentially unrelated to the probability of a company restating earnings. These include the independence of boards and audit committees and the extent to which outside auditors provide non-audit services to a firm. This empirical study is important having the fact that it demonstrates the fact that the prominent changes to corporate governance mechanisms have achieved its goals.

In the light of accounting scandals such as Enron and subsequent regulatory reforms like those introduced by the Sarbanes-Oxley Act of 2002, various studies had been conducted in the area of accounting and auditing, examining the role of corporate governance and various features of this complex mechanism. Most of the studies are focused of Agency Theory (Cohen et al., 2002), and examined how the monitoring roles of the board and the audit committee have been used to protect or fail to protect stockholder rights. What most of those studies have in common is the fact that they ignore the effect management may have on the governance process and sustain that independent boards must monitor management actions. Since those studies are based on Agency Theory the fact that they let out of discussion the role of management is not hard to predict since the role of management in corporate governance is somewhat inconsistent since the theory suggests that governance parties must monitor and thus be independent of management.

In response of accounting irregularities the frameworks for corporate governance in USA and elsewhere was re-examined. Among the key standards for international financial architecture that were modified were also the OECD Principles of Corporate Governance (that covers certain aspects of accounting and auditing in relation to corporate governance) considered to be essential to the soundness and stability of financial systems and as having a key role in measures to strengthen international financial architecture. following:

Five basic subjects are covered by the OECD Principles of Corporate Governance as

- protection of the rights of shareholders;

- equitable treatment of all shareholders comprising full disclosure of material information and also the prohibition of abusive self-dealing and insider trading;

- equitable treatment of all stakeholders as established by law and encouragement of cooperation between company and stakeholders;

- timely and accurate disclosure and transparency with respect to matters material to company performance, ownership and governance;

- strategic guidance of the company and effective monitoring of its management by the board of directors as well as the board's accountability to the company and its shareholders ensured by the corporate governance framework.

If we assess the Enron scandal having as a bases those principles we can conclude that most of them weren't respected. The lack of transparency was the main item that contributed to the breakdown of corporate governance in regarding of this particular company. Key items of Enron`s lack of transparency were represented by the manipulation of both its earnings figures and its balance sheet; manipulation that involved extensive use of creative accounting techniques like: special purpose entities, hedges and mark-to-market accounting. .

\section{Findings - Discussions based on corporate governance features that sustain the connection of the concept with creative accounting documented in empirical works}

The empirical studies that associated corporate governance with creative accounting were interested in assessing the role of the first in the occurrence of creative accounting and to assess empirically its magnitude. Studies like those conducted by Rajgopal et al., (1999); Beekes et al. (2002); Agarwal and Chadha (2005) are representative in this respect.

In any of those studies, various components of corporate governance mechanism are discussed in association with creative accounting features. The study conducted by Rajgopal et al. (1999), tests the impact on earnings management by institutional ownership. The empirical study 
conducted by Agarwal and Chadha (2005) tested for association between accounting restatements and the board of directors and the audit committee concluding based on their regression that there is a positive association. Beekes et al. (2002) examined the relationship between board of directors and accounting quality concluding that the first category has the power to influence the latter.

In the following figure we summarized various corporate governance factors that were examined in association with creative accounting in the literature.

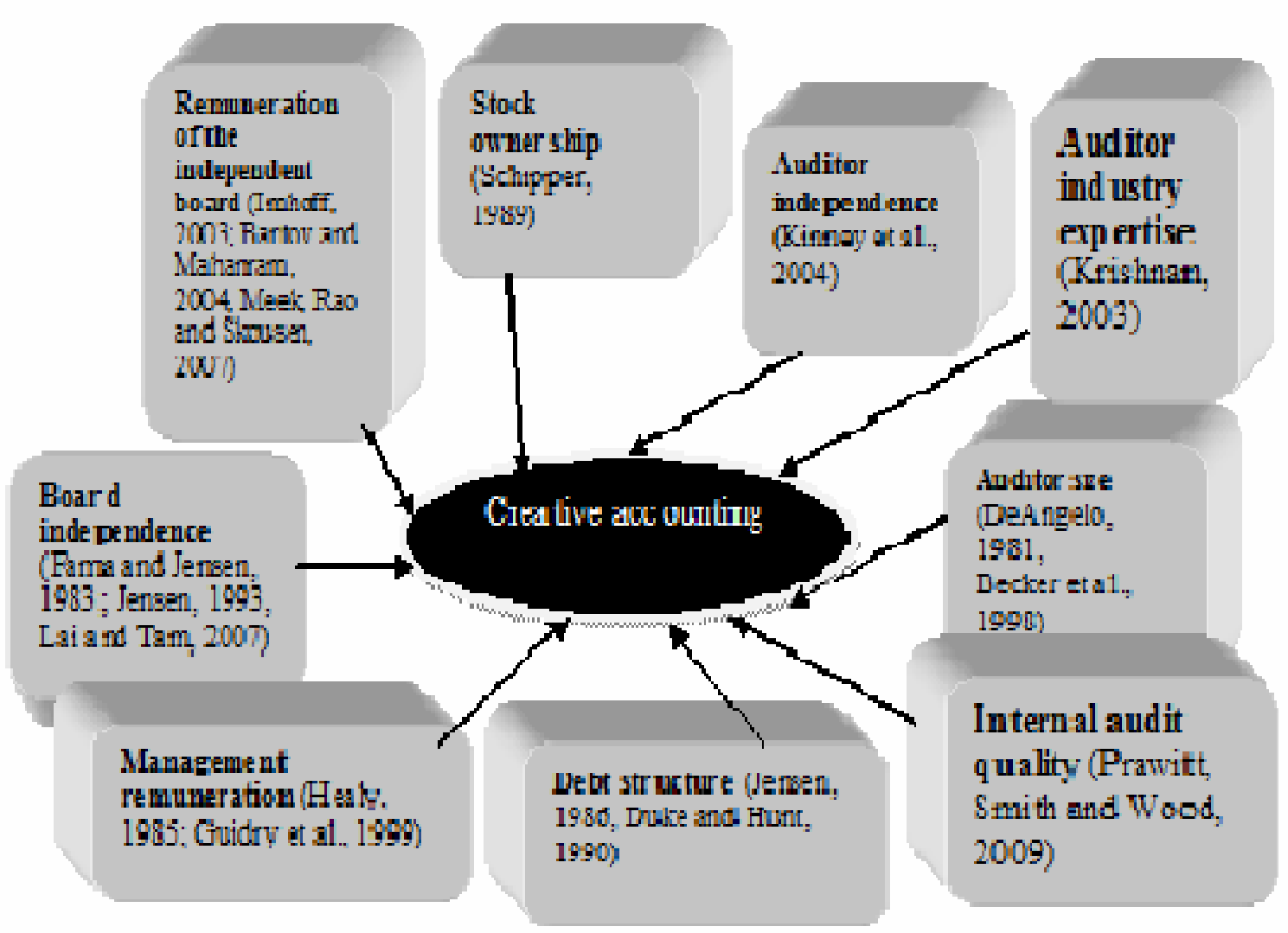

Figure No. 1 - Association between various corporate governance factor and creative accounting according to the literature

Jensen (1986) asserted that managers occasionally strive to defeat takeover activities by making their firm presume more debt. In this respect the author explains that takeovers can be for managers an unwanted demarche having the fact that this employs new ownership and established new management. The managers cab fight against this by increasing the level of debts and reduce the probability of taking place new offers for the existing shareholders. Other aspect that was examined was the debt contact constrains (Duke and Hunt, 1990) in association with opportunistic behavior.

Large stock shareholders are considered the most important group in the company and two features defines them: they are the most informed investors and they are interested in long-term performance of the company. Managers for improving their remuneration packages are interested in performing creative activities that in long term can affect the part of the rewards designated to those particular investors. In this context, the first category will is not interested in earnings management activities and will have more motivation to accomplish monitoring activities (Schipper, 1989).

Auditor independence is seen in the literature as a possible root for creative accounting occurrence. In this respect, Kinney et al., (2004), examined the non-audit fees paid to auditors and 
concluded that high non-audit fees paid to auditors are more likely to be related to creative accounting compared to high audit fees, as non-audit tasks produces higher profits than audit tasks. Frankel, Johnson and Nelson (2002) also documented a positive association between non-audit fees and earnings surprises and magnitude of discretionary accruals.

Becker et al. (1998) documented that small audit firms showed high discretionary accruals in the accounts compared to large auditing firms and concluded that the latter category is more effective in limit opportunistic behaviors that the first one. The study of the Becker et al., (1998) was conducted based on the believe that large audit firms with good brand name select their clients very good and will always chose the clients that are not engaging in creative accounting techniques (DeAngelo, 1981).

The independence of the board of directors is associated with protecting the interests of shareholders and election of top management (Jensen, 1993). According to Fama and Jensen (1983) the company's directors should keep a status by employing skill personnel who can take best decisions as well as execute those decisions promptly. In this context, creative accounting is considered to be negative associated with this particular feature of corporate governance. Lai and Tam (2007) conducted an empirical study in order to examine the impact of independent board of directors over the propensity of smoothing earnings and the conclusions revealed that Chinese firms that voluntary adopted independent directors as well as firms that have larger fraction of independent directors have less severe practice of income smoothing.

Auditor industry expertise was assessed in association with earnings management by Krishnan (2003) who documented that specialized auditors (measured in terms of both auditor market share in an industry and an industry share in the auditor's portfolio of client industries) mitigate accruals-based management more than non-specialist auditors influencing positively the quality of earnings.

The independent board can be a factor that has the power to restrict creative accounting until this is not related to the incentives offered to independent directors. In this respect, stock options schemes are calculated based on firm profitability. If this decreases managers may engage in manipulative schemes and the independent directors may tolerate this kind of behavior by not disclosing it (Imhoff, 2003). According to Bartov and Mahanram (2004), many top management directors have the incentive to time their stock option in such a way that it is exercised and then information is disclosed. The empirical study conducted by Meek, Rao and Skousen (2007) documented a positive relationship between CEO stock option compensation and discretionary accruals this implying that earnings management is more likely where stock options are a larger part of CEO compensation

When it comes to management remuneration, this is strongly connected to the financial performance of the company and as a consequence of this fact; the more profitable a company is the highest rewards managers will receive. In this respect, Healy (1985) sees this association as having the power to generate earnings management schemes. This vision is similar to Guidry et al. (1999) vision, as the latter documented that for receiving maximum bonus, managers make use of accrual decisions that boost the profitability.

Internal audit was also examined in association with the level of earnings management. The study conducted by Prawitt, Smith and Wood (2009) assessed the influence of internal auditors on earnings management occurrence measured by two separate proxies like: abnormal accruals and the propensity to meet or beat analysts forecast. The results of the empirical study documented that internal audit quality (measured based on their role in financial reporting) is associated with a moderation in the level of earnings management measured by the above proxies.

Most of those factors are considered corporate governance tools designed to restrict creative accounting but still some of them inspire it (e.g. management remuneration). Having the various misdeeds in accounting the importance of corporate governance instruments increased over time. 


\section{Conclusions}

Most of the corporate problems were associated in the literature with the separation of the ownership from the control of a corporation based in the Agency Theory precepts. In the modern frameworks of organization of the economic entities the agency relationship as described by the Agency Theory exists between owners and managers. The connection of corporate governance with creative accounting takes place in this context where managers will always try to maximize their own interest instead of the owner's interest.

The Agency Theory is only one of the theories that approached those concepts under the aegis of connectivity and based on its existence we can assert that our first research hypothesis was validated and the theoretical framework involved is the prove that this connection is treated not only at empirical level but also in fundamental one.

The spectacular increases in unexpected business failures and the ease of unscrupulous directors in expropriating other stakeholders, the limited role of auditors, the executive compensation based on company performance have brought concerns regarding corporate governance mechanisms efficiency (in this respect Stiles and Taylor (1993) study is representative since it approached the corporate governance weaknesses discussing them in the context of Maxwell scandal).

Most of the studies examined are debating those particular views while others focus more on the role of information asymmetry seen also as a root for creative accounting in this context. The lack of transparency in corporate governance mechanism and other weaknesses of this complex mechanism opened various doors for creative accounting. In the empirical studies approached the connection between these two concepts is evident and more than that the relationship is documented by empirical data, validating in this respect our second research hypothesis.

In the recent years, many of the mechanisms of corporate governance were improved by accounting; auditing and corporate governance regulations with the scope of gradually overcome those problems connected to opportunistic behavior. We used the term "limit" intentionally and not eradicate since we consider that this battle of corporate governance mechanisms with creative accounting as being a two-edged sword: some corporate governance features like independent board of directors will try to limit its occurrence while other governance properties like management remuneration packages will inspire it.

This study reflects in many ways our opinions regarding the connection of those two concepts that only in recent years have been considered important to approach from this point of view directly while aiming to be a warning sign regarding the responsibility of looking in all facets of the problems facing the contemporary economic environment.

\section{Limitations of the present study and scope for future research}

Since this study aim was to be an interpreter of the literature, the sampling of the literature is crucial. Since we used only the sources that were written in English language this could result in a important limitation of the study.

As further research involved we intend to assess empirically the association of corporate governance features and creative accounting in the Romanian economic environment since no study was been conducted so far in this respect.

Acknowledgements

${ }^{(*)}$ Investing in people! PhD scholarship, Project co-financed by the European Social Fund, SECTORAL OPERATIONAL PROGRAMME HUMAN RESOURCES DEVELOPMENT 2007 - 2013, Babeş-Bolyai University, Cluj-Napoca, Romania 
${ }^{(* *)}$ CNMP Acknowledgements This work was supported by CNMP, project number 92085/2008. The project is entitled "Developing a functional model for optimizing the national strategy regarding financial reporting within Romanian private sector entities".

\section{References}

1. Abrahamson, E., Park, C., 1994. Concealment of negative organizational outcomes: An agency theory perspective. Academy of Management Journal 37 (5), pp. 1302-1334.

2. Agrawal, A., Chadha, S., 2005. Corporate Governance and Accounting Scandals. Journal of Law and Economics 48, pp. 371-406.

3. Akerlof, G., 1970. The Market for Lemons: Quality Uncertainty and the Market Mechanism. Quarterly Journal of Economics 84, pp. 485-500.

4. Akerlof, G., 1976. The Economics of Caste and of the Rat Race and other Woeful Tales. Quarterly Journal of Economics 90, pp. 599-617.

5. Ali shah S.Z., Ali Butt S., Hasan, A., 2009. Corporate Governance and Earnings Management an Empirical Evidence Form Pakistani Listed Companies. European Journal of Scientific Research 26 (4), pp. 624-638.

6. Amat S. O., Gowthorpe C., 2004 „Creative Accounting: Nature, Incidence and Ethical Issues", Working Paper Series, Universitat Pompeu Fabra, No. 749, available on-line at http://ssrn.com/abstract=563364

7. Baginski, S.P., Hassell, J. M., Hillison, W. A., 2000. Voluntary causal disclosures: Tendencies and capital market reaction. Review of Quantitative Accounting and Finance 15 (4), pp. 371-389.

8. Bansal, P., Clelland, I., 2004. Talking trash: Legitimacy, impression management and unsystematic risk in the context of the natural environment. Academy of Management Journal 27 (1), pp. 93-103.

9. Bartov, E., Mohanram, P., 2004. Private Information, Earnings Manipulations, and Executive Stock- Option Exercises. The Accounting Review 79, pp. 889-920.

10. Beekes W., Pope P.F., Young S., 2002. The link between earnings conservatism and board composition. Evidence from UK, Corporate Governance. An International Review 12 (1), pp. 47-59.

11. Becker, C.L., DeFond, M.L., Jiambalvo, J., Subramanyam, K.R., 1998. The Effect of Audit Quality on Earnings Management. Contemporary Accounting Research 15 (1), pp. 1-24.

12. Citron, D., 1995. The Incidence of Accounting-based Covenants in the UK Public Debt Contracts: An Empirical Analysis. Accounting and Business Research 25 (9), pp.139-150.

13. Christensen, P.O., Feltham, J.A., 2005. Economics of Information, Volume II: Performance Evaluation., LLC, Springer-Verlag New York.

14. Cohen J., Krishnamoorthy G., Wright A., 2002. Corporate governance and the audit process. Contemporary Accounting Research 19, pp. 573-594.

15. Cormier, D., Aerts, W., Ledoux, M-J., Magnan, M., 2009. Attributes of Social and Human Capital Disclosure and Information Asymmetry between Managers and Investors. Canadian Journal of Administrative Sciences 26, pp. 71-88.

16. Davidson, R., Goodwin-Stewart, J., Kent, P., 2005. Internal governance structures and earnings management, Accounting and Finance 45, pp. 241-67.

17. DeAngelo L.E., 1981. Auditor size and audit quality. Journal of Accounting and Economics 3, pp. 183-199.

18. Dechow, P.M., Sloan, R.G., Sweeney, A.P., 1996. Causes and consequences of earnings manipulation: an analysis of firms subject to enforcement by the SEC. Contemporary Accounting Research 13 (1), pp. 1-36. 
19. DeFond, M.L., Jiambalvo J., 1994. Debt covenant violation and manipulation of accruals. Journal of Accounting and Economics 17, pp. 145-176.

20. Demski, J., 1994. Managerial Uses of Accounting Information. Kluwer, Boston.

21. Donaldson T., Werhane P.H., 1999. In Anonymous, Ethical Issues in Business: a Philosophical Approach. Upper Saddle River, Prentice-Hall Inc, NJ, pp. 251.

22. Duke J.C., Hunt H.G., 1990. An empirical examination of debt covenant restrictions and accounting related debt proxies. Journal of Accounting and Economics 12, pp. 45-63.

23. Dye, R., 1988. Earnings management in an overlapping generation's model. Journal of Accounting Research, pp. 195-235.

24. Fama, E., Jensen, M.C., 1983. Separation of ownership and control. Journal of Law and Economics 26, pp. 301-325.

25. Frankel, R., Johnson, M., Nelson, K., 2002. The relation between Auditors' Fees for Nonaudit Services and Earnings Management. The Accounting Review 77 (Supplement), pp. 71105.

26. Gowthorpe, C., Amat, S.O., 2005. Creative Accounting: Some Ethical Issues of Macro- and Micro-Manipulation. Journal of Business Ethics 57, pp. 55-64.

27. Guidry, F., Leone, A., Rock, S. 1999. Earnings-based bonus plans and earnings management business unit managers. Journal of Accounting and Economics 26, pp. 113-142.

28. Healy, P. 1985. The effect of bonus schemes on accounting-based dividend covenants. Journal of Accounting and Economics 7, pp. 85-107.

29. Hooghiemstra, R., 2000. Corporate communication and impression management - New perspectives why companies engage in social reporting. Journal of Business Ethics 27, pp. $55-68$.

30. Jaggi, B., Leung, S., 2007. Impact of family dominance on monitoring of earnings management by audit committees: evidence from Hong Kong. Journal of International Accounting, Auditing and Taxation 16 (1), pp. 27-50.

31. Jensen, M.C., 1986. Agency costs of free cash flow, corporate finance and takeovers. American Economic Review 76 (2), pp, 323-329.

32. Jensen, M.C., 1993. The modern industrial revolution, exit, and the failure of internal control systems. Journal of Finance 48 (2), pp. 831-880.

33. Imhoff, E.A., 2003. Accounting quality, auditing and corporate governance. Accounting Horizons 17 (Supplement) pp. 117-128.

34. Kinney, W.R., Palmrose, Z.V., Scholz, S., 2004. Auditor independence, non-audit services and restatements: Was the government right? Journal of Accounting Research 42 (3), pp. 561-588.

35. Krishnan, G., 2003. Does Big 6 Auditor Industry Expertise's Constrain Earnings Management? Accounting Horizons 17 (1), pp. 1-16.

36. Lai, L., Tam, H., 2007. Independent Directors and the Propensity to Smooth Earnings: A Study of Corporate Governance in China. The Business Review, Cambridge 7 (1), pp. 328335.

37. Meek, G.K., Rao, R.P., Skousen, C.J., 2007. Evidence on factors affecting the relationship between CEO stock option compensation and earnings management. Review of Accounting and Finance 6 (3), pp. 304-323.

38. Meckling, W.H., Jensen, M.C., 1976. Theory of the Firm: Managerial Behavior, Agency Costs and Ownership Structure in Michael C. Jensen (Eds.) A Theory of the Firm: Governance, Residual Claims and Organizational Forms, Harvard University Press.

39. Metcalf, L., 1977. The Accounting Establishment, Staff studies as the Chairman of the US Senate Subcommittee. The United States Government Printing Office Washington, D.C, pp. 188. 
40. Mirrlees J., 1971. An Exploration in the Theory of Optimum Income Taxation. Review of Economic Studies 38, pp. 175-208.

41. Naser, K., 1993. Creative financial accounting: its nature and use. Hemel Hempstead, Prentice Hall, pp. 2.

42. Ogden, S., Clarke, J., 2005. Customer disclosures, impression management and the construction of legitimacy: Corporate reports in the UK privatized water industry. Accounting, Auditing and Accountability Journal 18 (3), pp. 313 -345.

43. Perry, S. E., Williams, T.H., 1994. Earnings Management Preceding Management Buyout Offers. Journal of Accounting and Economics 18, pp. 157-179.

44. Prawitt, D.F., Smith, J.L., Wood, D.A., 2009. Internal Audit Quality and Earnings Management. The Accounting Review, 84 (4), pp. 1255-1280.

45. Rajgopal, S., Venkatachalam, M., Jiambalvo, J. 1999 „Is institutional ownership associated with earnings management and the extent to which stock prices reflect future earnings?" Working paper, University of Washington.

46. Rangan, S., 1998. Earnings Management and the Performance of Seasoned Equity Offerings. Journal of Financial Economics 50, pp. 101-122.

47. Richardson, V.J., (2000), Information Asymmetry and Earnings Management: Some Evidence. Review of Quantitative Finance and Accounting 15 (4), pp. 325-347.

48. Ronen J., Yaari V.L., 2002. Incentives for voluntary disclosure. Journal of Financial Markets 5 (3), pp. 349-390.

49. Rothschild, M., Stiglitz, J., 1976. Equilibrium in Competitive Insurance Markets: An Essay on the Economics of Imperfect Information. Quarterly Journal of Economics 95, pp. 629649.

50. Schipper, K., 1989. A commentary on earnings management. Accounting Horizons 3 (4), pp. 91-102.

51. Shleifer, A., Vishny, R.W., 1997. The Limits of Arbitrage. The Journal of Finance 52 (1), pp. 35-55.

52. Spence M., 1973. Job Market Signaling. Quarterly Journal of Economics, 87, pp. 355-374.

53. Smith Terry, 1992. Accounting for Growth: Stripping the Camouflage from Company Accounts. Century Business Publications, London.

54. Stiles P., Taylor B., 1993. Maxwell-The Failure of Corporate Governance. Corporate Governance 1 (1), pp. 34-45.

55. Sydserff, R., Weetman, P., 1999. A texture index for evaluating accounting narratives: An alternative to readability formulae. Accounting, Auditing and Accountability Journal 12 (4), pp. 459-488.

56. Trueman, B., Titman, S., 1988. An explanation for accounting income smoothing. Journal of Accounting Research 26, pp. 127-139.

57. Vickrey, W., 1945. Measuring Marginal Utility by Reactions to Risk. Econometrica 13, pp. 319-333.

58. Warfield, T., Wild, J., Wild, K., 1995. Managerial ownership, accounting choices and informativeness of earnings. Journal of Accounting and Economics 20, pp. 61-91. 